\title{
Galactosamine-Induced Acute Liver Injury in Rats Reduces Hepatic $\alpha$-Tocopherol Transfer Protein Production
}

\author{
Asako TAKENAKA ${ }^{1, *}$, Akiko KITA ${ }^{1}$, Masafumi IKEYA ${ }^{1}$, Hiroyuki ARAI ${ }^{2}$ and Kiharu IGARASHI ${ }^{1}$ \\ ${ }^{1}$ Department of Bioresource Engineering, Faculty of Agriculture, Yamagata University, Yamagata \\ 997-8555, Japan \\ ${ }^{2}$ Graduate School of Pharmaceutical Sciences, The University of Tokyo, Tokyo 113-0033, Japan
}

(Received October 5, 2006)

\begin{abstract}
Summary The liver plays the main role in the secretion of food-derived $\alpha$-tocopherol into the circulation through the functioning of $\alpha$-tocopherol transfer protein $(\alpha$-TTP). However, the effect of liver disease on $\alpha$-TTP level and $\alpha$-tocopherol metabolism has not been clarified. We examined the amount of liver $\alpha$-TTP and its effect on serum $\alpha$-tocopherol concentration in liver injury. Male Wistar rats were injected intraperitoneally with D-galactosamine at 800 $\mathrm{mg} / \mathrm{kg}$ body weight, and liver and serum lipid concentrations, $\alpha$-tocopherol concentrations, and hepatic $\alpha$-TTP mRNA and protein levels were measured at 24, 48 , and $72 \mathrm{~h}$ after injection. On the basis of body weight changes and serum transaminase activities, the livers were found to be in an injured state 24 and $48 \mathrm{~h}$ after galactosamine injection but had recovered by $72 \mathrm{~h}$. The hepatic $\alpha$-TTP mRNA level was reduced throughout the experimental period, and at $48 \mathrm{~h}$ after injection the $\alpha$-TTP protein level had begun to decrease. Lipid and $\alpha$-tocopherol concentrations in the serum were decreased at 24 and $48 \mathrm{~h}$ after injection and increased at $72 \mathrm{~h}$. Liver lipid concentrations were increased at 24 and $48 \mathrm{~h}$ after injection, but the liver $\alpha$-tocopherol concentration was unchanged. These results show that galactosamine-induced liver injury decreases hepatic $\alpha$-TTP synthesis in rats. Serum $\alpha$-tocopherol concentration was not directly affected by the acute change in hepatic $\alpha$-TTP level, suggesting that the chronic changes in $\alpha$-TTP activity would be necessary to regulate serum $\alpha$-tocopherol concentration.
\end{abstract}

Key Words $\alpha$-tocopherol transfer protein, $\alpha$-TTP, galactosamine, liver injury, rat

$\alpha$-Tocopherol is the most active form of vitamin $\mathrm{E}$ and is the most potent lipid-soluble antioxidant in biological membranes. After intestinal absorption, vitamin $\mathrm{E}$ is packaged into chylomicrons and carried to the liver. $\alpha$ Tocopherol transfer protein $(\alpha$-TTP), a liver cytosolic protein, binds to $\alpha$-tocopherol with higher affinity than to other forms of vitamin $\mathrm{E}$ and transfers $\alpha$-tocopherol to lipoproteins in the circulation (1). It has now been established that $\alpha$-TTP, through this mechanism, is a major determinant of plasma $\alpha$-tocopherol level. In fact, humans with a defective $\alpha$-TTP gene have severe vitamin E deficiency (2), and depletion of the $\alpha$-TTP gene in mice results in severely reduced plasma and tissue $\alpha$-tocopherol concentrations (3-5). Although genetic $\alpha$-TTP deficiency severely affects serum and

\footnotetext{
* To whom correspondence should be addressed at present address: School of Agriculture, Meiji University, 1-1-1 Higashimita, Tama-ku, Kawasaki, Kanagawa 214-8571, Japan

E-mail: takenaka@isc.meiji.ac.jp

Abbreviations: AGPC, acid guanidium thiocyanate-phenolchloroform; ALT, alanine aminotransferase; AST, aspartate aminotransferase; HPLC, high-performance liquid chromatography; LDH, lactate dehydrogenase; PL, phospholipids; TG, triglyceride; $\alpha$-TTP, $\alpha$-tocopherol transfer protein; TC, total cholesterol.
}

peripheral tissue $\alpha$-tocopherol concentrations, effects of the reduction of hepatic $\alpha$-TTP level on serum or liver $\alpha$-tocopherol under physiological conditions have been reported in only a very few cases $(6,7)$.

Since liver $\alpha$-TTP plays a major role in supplying $\alpha$ tocopherol to the circulation, reduced $\alpha$-tocopherol secretion into the blood might occur in animals with liver injury. In fact, decreased serum $\alpha$-tocopherol concentrations have been reported in patients with hepatitis $(8-10)$, although the effects of various liver diseases on serum $\alpha$-tocopherol are still controversial (11). This study was designed to determine the effects of liver injury on hepatic $\alpha$-TTP level and liver and serum concentrations of $\alpha$-tocopherol, with galactosamineinduced liver injury as an animal model of human hepatitis.

Galactosamine-induced liver injury is a commonly used animal model of human hepatitis. After injection, galactosamine is metabolized to UDP-hexosamines and UDP- $\mathrm{N}$-acetylhexosamines in the hepatocytes, transiently blocks transcription and protein synthesis in those cells, and induces necrosis in the hepatic parenchymal cells (12). Recent studies have demonstrated that apoptosis also contributes to galactosamineinduced liver injury by increasing TNF- $\alpha$ production 


\section{(13-15).}

We injected male Wistar rats intraperitoneally with D-galactosamine, and measured their liver and serum $\alpha$-tocopherol concentrations and hepatic $\alpha$-TTP mRNA and protein levels at 24,48 , and $72 \mathrm{~h}$ after injection.

\section{Materials and Methods}

Materials. Anti-rat $\alpha$-TTP monoclonal antibody was prepared by Sato et al. as described previously (16). Other chemicals were of reagent grade, available commercially.

Animal experiment. The care and use of the rats followed the institutional guidelines of Yamagata University. Six-week-old male Wistar rats (Japan SLC, Hamamatsu, Japan) were housed individually in stainless-steel cages with a $12 \mathrm{~h}$ light: dark cycle (06:0018:00) at a temperature of $22-24^{\circ} \mathrm{C}$ and a relative humidity of about 55\%. The rats were allowed free access to water and fed a commercial diet for $3 \mathrm{~d}$ to allow acclimation to these conditions.

The rats were divided randomly into six groups $(n=5$ for control groups and $n=8$ for galactosamine-injected groups), and rats in all groups were fed normal diets consisting of $200 \mathrm{~g} / \mathrm{kg}$ casein, $50 \mathrm{~g} / \mathrm{kg}$ corn oil, $437 \mathrm{~g} /$ $\mathrm{kg} \alpha$-cornstarch, $218 \mathrm{~g} / \mathrm{kg}$ sucrose, $50 \mathrm{~g} / \mathrm{kg}$ cellulose, $10 \mathrm{~g} / \mathrm{kg}$ vitamin mixture (AIN97, obtained from Oriental Yeast Co., Tokyo, Japan), and $35 \mathrm{~g} / \mathrm{kg}$ mineral mixture (AIN97, obtained from Oriental Yeast Co.). Water and food were provided ad libitum. On day 4, three groups of rats were injected intraperitoneally with Dgalactosamine dissolved in water at a dose of $800 \mathrm{mg} /$ $\mathrm{kg}$ body weight, and rats in the other groups were injected with water. Rats from each group were anesthetized and blood was collected by cardiac puncture at 24,48 , or $72 \mathrm{~h}$ after galactosamine injection. A section of the liver was excised, quickly frozen in liquid nitrogen, and stored at $-80^{\circ} \mathrm{C}$ until use.

Determination of liver and serum $\alpha$-tocopherol concentrations. $\alpha$-Tocopherol in the liver and serum was extracted according to the procedure of Harada et al. (17). $\alpha$-Tocopherol concentration was determined fluorometrically by high-performance liquid chromatography as described previously (18).

Determination of serum ALT, AST, and LDH activities. Alanine aminotransferase (ALT) and aspartate aminotransferase (AST) activities were determined with the GPT-UV test Wako and GOT-UV test Wako (Wako Pure Chemical Industries, Ltd., Osaka, Japan), respectively. Lactate dehydrogenase (LDH) activity was measured as described by Wroblewski and LaDue (19). Briefly, serum $(50 \mu \mathrm{L})$ was added to $2 \mathrm{~mL}$ of $50 \mathrm{mmol} / \mathrm{L}$ phosphate buffer ( $\mathrm{pH} 7.5$ ) containing $0.62 \mathrm{mmol} / \mathrm{L}$ lithium pyruvate and $0.18 \mathrm{mmol} / \mathrm{L} \mathrm{NADH}$, which had been prewarmed at $35^{\circ} \mathrm{C}$. The rate of decrease of absorbance at a wavelength of $340 \mathrm{~nm}$ was measured. $\mathrm{LDH}$ activity (unit/mL) was defined as 1 unit $=1,720 \times($ decrease in absorbance at $340 \mathrm{~nm}$ for $2 \mathrm{~min}$ ).

Analysis of lipid content in serum and liver. Liver lipids were extracted and purified by the method of Folch et al. (20). The triglyceride (TG), phospholipid (PL) and total cholesterol (TC) contents of the serum and liver were determined with Triglyceride E-test kit, Phospholipid Btest kit and Cholesterol E-test kit, respectively (Wako Pure Chemical Industries, Ltd.).

Northern blot analysis. Total RNA was prepared from the liver according to a modified method of acid guanidium thiocyanate-phenol-chloroform (AGPC) extraction $(21,22)$, as described previously (23). Northern blot analysis was performed as described previously (23). The cDNA fragment of rat $\alpha$-TTP (517792 bp) was obtained by RT-PCR and was used as a probe. The intensity of each band obtained from Northern blot analysis was quantified by the Fujix BAS 1800 system (Fuji Film Co., Tokyo, Japan).

Western blot analysis. A sample of $0.2 \mathrm{~g}$ of liver was homogenized on ice in buffer $(50 \mathrm{mmol} / \mathrm{L}$ Tris- $\mathrm{HCl}(\mathrm{pH}$ 7.5), $50 \mathrm{mmol} / \mathrm{L} \mathrm{NaCl}, 1 \%(\mathrm{w} / \mathrm{v})$ Triton $\mathrm{X}-100,0.1 \%$ SDS, $0.1 \mathrm{mg} / \mathrm{mL}$ phenylmethanesulfonyl fluoride, 0.05 $\mathrm{mg} / \mathrm{mL}$ aprotinin, $0.01 \mathrm{mg} / \mathrm{mL}$ leupeptin, $0.01 \mathrm{mg} / \mathrm{mL}$ pepstatin). The homogenized liver was centrifuged $\left(20,100 \times g, 4^{\circ} \mathrm{C}, 20 \mathrm{~min}\right)$ twice, and the supernatant of the second centrifugation was used as the liver protein sample. Ten micrograms of each protein sample was electrophoresed and transferred to a nylon membrane (Hybond-N+, Amersham Japan, Tokyo, Japan). After the membrane had been blocked with BSA and incubated with anti- $\alpha$-TTP antibody $(1: 1,000)$ followed by probing for $1 \mathrm{~h}$ with anti-mouse IgG conjugated with horseradish peroxidase $(1: 1,000)$ (Santa Cruz Biotechnology, Inc., Santa Cruz, CF, USA), $\alpha$-TTP was detected by measuring chemical luminescence using ECL Western Blotting kit (Amersham Japan) and a lumino-image analyzer LAS1000 system (Fujix, Tokyo, Japan).

Statistics. Data are expressed as means \pm SE. The homogeneity of variance between treatments was verified by Bartlett's test. Differences between two groups were tested by Student's t-test. Differences were considered significant at $p<0.05$ (Statcel, OMS Publishing Inc., Saitama, Japan).

\section{Results and Discussion}

To elucidate whether galactosamine injection induced liver injury, we measured food intake, body weight, and serum transaminase activity. The food intakes of galactosamine-injected rats were reduced to 75 to $80 \%$ of the control level. Body weight gains were also reduced until $48 \mathrm{~h}$ after galactosamine injection and then increased between 48 and $72 \mathrm{~h}$ after injection. The liver weight of galactosamine-injected rats was reduced $48 \mathrm{~h}$ after injection but had recovered by $72 \mathrm{~h}$ (Table 1). Serum activities of aminotransferases (ALT and AST) and LDH were significantly higher in galactosamine-injected rats than in controls at 24 and $48 \mathrm{~h}$ after injection but returned close to control levels by $72 \mathrm{~h}$ after injection (Table 1). Galactosamineinjected rats that showed no changes in serum AST, ALT, or LDH activities were regarded as not being liverinjured and samples from those rats were not used in further experiments. These data show that liver injury was present in galactosamine-injected rats 24 and $48 \mathrm{~h}$ 
Table 1. Effect of $\beta$-D-galactosamine injection on food intake, body weight gain, liver weight, serum AST, ALT, LDH activities, and serum and liver lipids concentrations in rats.

\begin{tabular}{|c|c|c|c|c|c|c|}
\hline & \multicolumn{2}{|c|}{$24 \mathrm{~h}$} & \multicolumn{2}{|c|}{$48 \mathrm{~h}$} & \multicolumn{2}{|c|}{$72 \mathrm{~h}$} \\
\hline & $\operatorname{con}(n=5)$ & $\operatorname{gal}(n=5)$ & $\operatorname{con}(n=5)$ & $\operatorname{gal}(n=6)$ & $\operatorname{con}(n=5)$ & $\operatorname{gal}(n=7)$ \\
\hline Food intake (g) & $13.6 \pm 0.2$ & $10.2 \pm 0.3^{*}$ & $27.4 \pm 0.7$ & $20.8 \pm 1.1^{*}$ & $39.9 \pm 0.9$ & $31.3 \pm 1.4^{*}$ \\
\hline Body weight gain (g) & $5.36 \pm 0.52$ & $-1.42 \pm 0.60^{*}$ & $10.7 \pm 0.5$ & $-0.05 \pm 1.30^{*}$ & $13.4 \pm 0.5$ & $6.41 \pm 0.54^{*}$ \\
\hline Liver weight $(\mathrm{g})$ & $5.37 \pm 0.05$ & $4.69 \pm 0.09 *$ & $5.60 \pm 0.06$ & $4.45 \pm 0.24^{*}$ & $5.39 \pm 0.19$ & $5.56 \pm 0.18$ \\
\hline Liver weight ( $\%$ of body weight) & $4.49 \pm 0.05$ & $4.09 \pm 0.08^{*}$ & $4.48 \pm 0.04$ & $3.95 \pm 0.20^{*}$ & $4.22 \pm 0.10$ & $4.63 \pm 0.10^{*}$ \\
\hline Serum AST activity (IU/L) & $33.4 \pm 3.6$ & $246 \pm 37^{*}$ & $52.2 \pm 5.7$ & $211 \pm 17^{*}$ & $45.9 \pm 6.7$ & $63.0 \pm 3.9^{*}$ \\
\hline Serum ALT activity (IU/L) & $55.6 \pm 4.8$ & $198 \pm 26^{*}$ & $62.5 \pm 4.5$ & $180 \pm 12^{*}$ & $74.5 \pm 4.9$ & $73.5 \pm 4.9$ \\
\hline Serum LDH activity (IU/L) & $387 \pm 64$ & $1319 \pm 131^{*}$ & $483 \pm 38$ & $628 \pm 34^{*}$ & $540 \pm 57$ & $470 \pm 73$ \\
\hline Serum TG $(\mathrm{mg} / \mathrm{mL})$ & $0.891 \pm 0.044$ & $0.359 \pm 0.040^{*}$ & $0.992 \pm 0.136$ & $0.681 \pm 0.071$ & $0.756 \pm 0.084$ & $1.48 \pm 0.07^{*}$ \\
\hline Serum PL (mg/mL) & $1.48 \pm 0.04$ & $0.741 \pm 0.055^{*}$ & $1.54 \pm 0.02$ & $1.08 \pm 0.11^{*}$ & $1.46 \pm 0.07$ & $2.52 \pm 0.12^{*}$ \\
\hline Serum TC (mg/mL) & $0.716 \pm 0.021$ & $0.301 \pm 0.029^{*}$ & $0.841 \pm 0.024$ & $0.627 \pm 0.072^{*}$ & $0.748 \pm 0.030$ & $1.49 \pm 0.06^{*}$ \\
\hline Liver TG (mg/g liver) & $4.38 \pm 0.41$ & $13.3 \pm 1.5^{*}$ & $5.02 \pm 0.52$ & $10.1 \pm 1.5^{*}$ & $5.63 \pm 0.64$ & $6.73 \pm 0.44$ \\
\hline LiverPL (mg/g liver) & $15.0 \pm 0.9$ & $17.4 \pm 0.4^{*}$ & $14.5 \pm 0.4$ & $14.6 \pm 0.3$ & $15.8 \pm 0.3$ & $14.1 \pm 0.2^{*}$ \\
\hline Liver TC (mg/g liver) & $1.76 \pm 0.11$ & $2.87 \pm 0.08^{*}$ & $1.84 \pm 0.05$ & $3.17 \pm 0.25^{*}$ & $1.99 \pm 0.06$ & $2.25 \pm 0.08^{*}$ \\
\hline
\end{tabular}

AST, aspartate aminotransferase; ALT, alanine aminotransferase; LDH, lactate dehydrogenase; TG, triglyceride; PL, phospholipid; TC, total cholesterol; con, control group; gal, $\beta$-D-galactosamine-injected group.

Values are expressed as means \pm SE.

* Significant differences compared with control group.

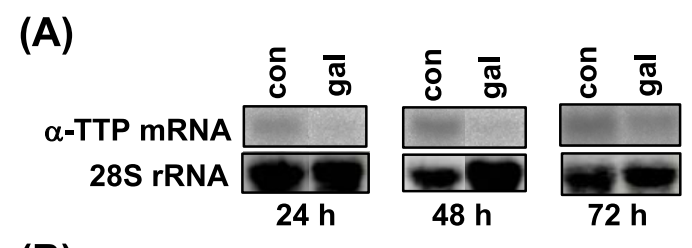

(B)

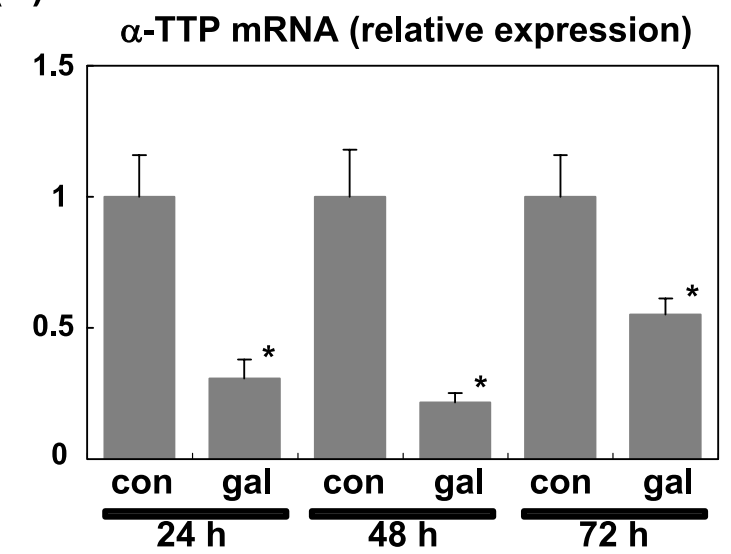

(C)

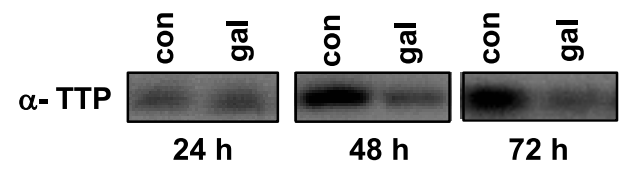

(D)

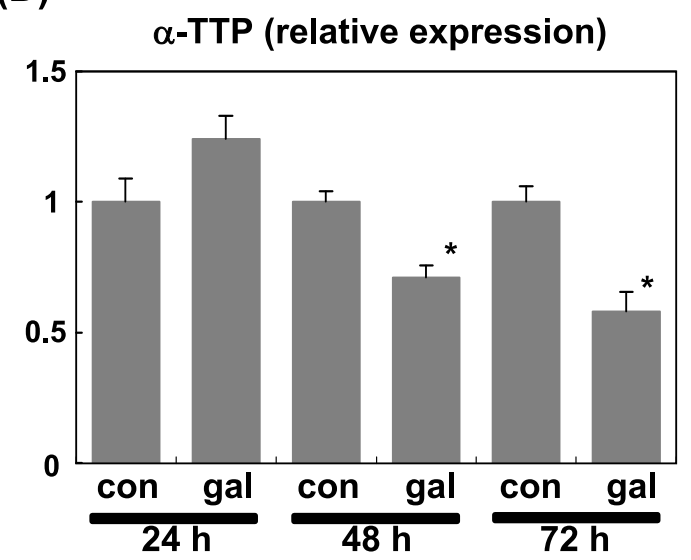

Fig. 1. Hepatic $\alpha$-TTP mRNA and protein level in control rats (con) and $\beta$-D-galactosamine-injected rats (gal) at 24,48 , and $72 \mathrm{~h}$ after injection. (A) A representative result of Northern blot analysis is shown together with levels of membranetransferred 28S rRNA. (B) The intensity of each band in Northern blotting was determined and expressed as a value relative to that of the controls. (C) A representative result of Western blot analysis is shown. (D) The intensity of each band in Western blotting was determined and expressed as a value relative to that of the controls. Values are means \pm SE and are expressed relative to those of the control group. * Significantly different from the control group, $p<0.05$.

after injection, but that the galactosamine-injected rats had recovered from the injury by $72 \mathrm{~h}$ after injection; these observations are consistent with those of a previous report (24).

Because $\alpha$-tocopherol is lipid soluble and is transported in lipoproteins, liver and serum lipid concentrations were measured to allow comparisons with $\alpha$-tocopherol concentration. Serum TG, PL, and TC concent- rations of galactosamine-injected rats were lower than those of controls 24 and $48 \mathrm{~h}$ after injection, and significantly higher $72 \mathrm{~h}$ after injection. Liver TG and TC concentrations were significantly higher in galactosamineinjected rats than in controls 24 and $48 \mathrm{~h}$ after injection, but by $72 \mathrm{~h}$ they had returned close to those in the controls. Liver PL concentration was higher in galactosamine-injected rats than in controls $24 \mathrm{~h}$ after injec- 
(A)

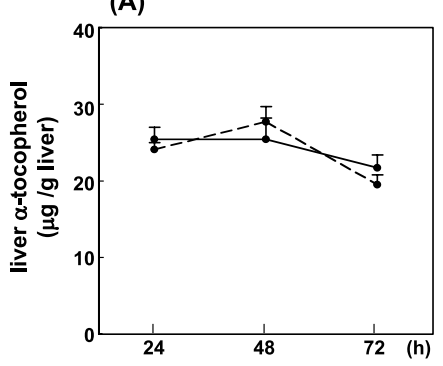

(B)

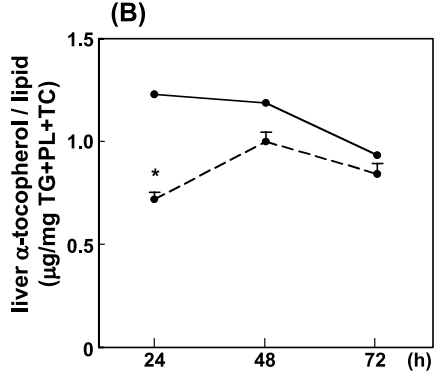

(C)

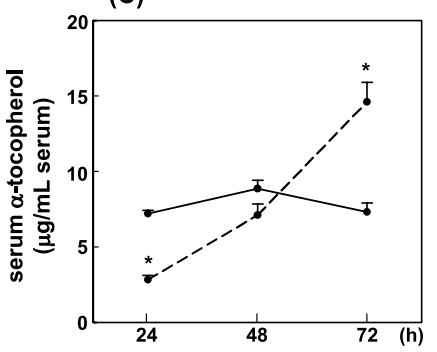

(D)

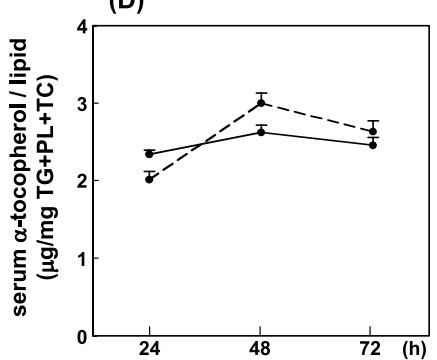

Fig. 2. Liver and serum $\alpha$-tocopherol concentrations in control rats (solid lines) and $\beta$-D-galactosamine-injected rats (dashed lines) at 24,48 , and $72 \mathrm{~h}$ after galactosamine injection. Values are means \pm SE. * Significantly different from control group, $p<0.05$.

tion but was lower at $72 \mathrm{~h}$ than in controls (Table 1 ). Galactosamine-injected rats therefore had fatty livers 24 and $48 \mathrm{~h}$ after injection, as described previously, probably because of decreased $\beta$-oxidation (25).

$\alpha$-TTP mRNA and protein contents were measured to elucidate the effect of galactosamine-induced acute liver injury on $\alpha$-TTP synthesis. Typical results of Northern blot analysis, together with the amount of $28 \mathrm{~S}$ rRNA transferred to the nylon membrane, are shown in Fig. 1A. The hepatic $\alpha$-TTP mRNA level was significantly lower in galactosamine-injected rats 24 and $48 \mathrm{~h} \mathrm{(20-30 \%} \mathrm{of} \mathrm{the} \mathrm{control} \mathrm{level),} \mathrm{and} 72 \mathrm{~h}(50 \%$ of the control level) after galactosamine injection (Fig. $1 \mathrm{~B})$, indicating that the $\alpha$-TTP mRNA level was influenced directly by the severity of liver injury. The reduced expression of hepatic $\alpha$-TTP mRNA was probably caused by the induction of necrosis and apoptosis in the liver parenchymal cells or by the reduction of liver-specific function by the galactosamine injection $(26,27)$. Although the food intake of the galactosamine-injected rats was reduced throughout the experimental period, this reduction was not the main cause of the decline in $\alpha$-TTP mRNA levels, because restriction of food intake (48-h fasting) did not affect hepatic $\alpha$-TTP mRNA level in our previous study (data not shown).

The $\alpha$-TTP protein content had begun to decrease in galactosamine-injected rats by $48 \mathrm{~h}$ after galactosamine injection and at $72 \mathrm{~h}$ was still lower than that in the controls (30\% of the control level) (Fig. 1C, D). The relative amount of $\alpha$-TTP in whole liver was also significantly lower in galactosamine-injected rats at 48 and $72 \mathrm{~h}$ after injection $(1.02 \pm 0.05$ at $24 \mathrm{~h}, 0.57 \pm 0.05$ at $48 \mathrm{~h}$ and $0.52 \pm 0.07$ at $72 \mathrm{~h}$, relative to a control group value of 1). The time lag between the decreases in $\alpha$-TTP mRNA and protein levels suggested that $\alpha$-TTP protein had a long half-life and was therefore not influ- enced immediately by decreased mRNA expression.

To examine the effect of hepatic $\alpha$-TTP content on $\alpha$ tocopherol metabolism, liver and serum $\alpha$-tocopherol concentrations were measured. Although it has been reported that hepatic $\alpha$-tocopherol concentration is well correlated with liver lipid concentrations in patients with liver disease (11) and in galactosamine-injected rats (28), we found that hepatic $\alpha$-tocopherol concentration was unchanged and was not correlated with liver lipid concentrations (Fig. 2A, B). These results suggest that hepatic lipid and $\alpha$-tocopherol concentrations are regulated independently. Serum $\alpha$-tocopherol concentration was lower in galactosamine-injected rats $24 \mathrm{~h}$ after injection and higher $72 \mathrm{~h}$ after injection than in controls (Fig. 2C). Therefore, despite the decreased hepatic $\alpha$-TTP protein level in galactosamine-injected rats at 48 and $72 \mathrm{~h}$ after injection, the serum $\alpha$-tocopherol concentration did not differ from that in control rats $48 \mathrm{~h}$ after injection and was even higher $72 \mathrm{~h}$ after injection. These results showed that a reduction in hepatic $\alpha$-TTP level did not immediately reduce serum $\alpha$-tocopherol concentration. The amount of $\alpha$-TTP in the liver may be excess to transfer $\alpha$-tocopherol from the liver to the blood, or the $\alpha$-tocopherol pool in the serum and peripheral tissues may have been too large to be affected by the acute reduction in $\alpha$-tocopherol secretion by the liver. On the other hand, the serum $\alpha$-tocopherol concentration was well correlated with serum lipid concentrations (Fig. 2D). The tocopherol-to-lipid ratio in the serum remains unchanged in liver cirrhosis patients despite a low serum $\alpha$-tocopherol level (29), and the serum $\alpha$-tocopherol concentration is well correlated with the serum cholesterol concentration in patients with liver diseases $(8)$. These results indicate that lipids and $\alpha$-tocopherol might have a common machinery-such as an ATP-binding cassette transporter or 
microsomal transfer protein-by which they are secreted from the liver. $\alpha$-TTP may function to transport $\alpha$-tocopherol to these transport molecules. Taken together, the available evidence indicates that serum $\alpha$-tocopherol concentration is correlated with serum lipid concentration but is not affected by hepatic $\alpha$-TTP level in animals with acute liver injury.

Since $\alpha$-TTP knockout mice have very low $\alpha$-tocopherol concentrations in the serum and peripheral tissues, it has been suggested that extremely low levels of hepatic $\alpha$-TTP could reduce $\alpha$-tocopherol transfer activity from the liver to the serum (3-5). In the case of $\alpha$ TTP hetero-knockout mice, in which hepatic $\alpha$-TTP content is about $50 \%$ of that in normal animals, serum and peripheral $\alpha$-tocopherol concentrations at 3 mo of age are 30\% lower than normal (4). Therefore, a 50\% decrease in $\alpha$-TTP in this study should have been sufficient to affect the serum $\alpha$-tocopherol concentration. Probably, a decrease in $\alpha$-TTP production over a longer period would have reduced the serum $\alpha$-tocopherol concentration.

The decreased serum $\alpha$-tocopherol concentrations seen at 24 and $48 \mathrm{~h}$ after injection may have been induced by the accelerated consumption of $\alpha$-tocopherol under increased oxidative stress. It has been reported that galactosamine injection increases lipid peroxidation and decreases the contents of non-enzymatic antioxidants (glutathione, vitamin $\mathrm{C}$ and vitamin E) in rats; these alterations were normalized by oral intake of an antioxidant $(18,30)$. However, it is not easy to estimate the contribution of $\alpha$-tocopherol consumption in decreasing serum $\alpha$-tocopherol level in galactosamine-injected animals, because antioxidant treatment may inhibit liver injury and maintain serum $\alpha$-tocopherol levels as well as reduce $\alpha$-tocopherol consumption. As the changes in serum $\alpha$-tocopherol concentration were well correlated with lipid concentrations in our study, liver injury may affect serum $\alpha$ tocopherol level mainly through the alteration of lipid transport.

In conclusion, these results indicate that galactosamine-induced liver injury decreases $\alpha$-TTP production in rats; however, serum $\alpha$-tocopherol concentration is not directly affected by the acute changes in hepatic $\alpha$-TTP level.

\section{Acknowledgments}

We thank Dr. Shin-Ichiro Takahashi (The University of Tokyo, Tokyo) for his helpful discussions during the experiments and for his suggestions during the preparation of this manuscript. This work was supported by a Grant-in-Aid from the Scientific Research Fund of the Ministry of Education, Science, Culture and Sports, Japan (\#13760093).

\section{REFERENCES}

1) Traber MG, Arai H. 1999. Molecular mechanisms of vitamin E transport. Ann Rev Nutr 19: 343-355.

2) Hamida CB, Doerflinger N, Belal $S$, Linder C, Reutenauer L, Dib C, Gyapay G, Vignal A, Le Paslier D, Cohen D,
Pandolfo M, Mokini V, Movelli G, Hentati F, Ben Hamida M, Mandel J-L, Koenig M. 1993. Localization of Friedreich ataxia phenotype with selective vitamin $\mathrm{E}$ deficiency to chromosome 8q by homozygosity mapping. Nature Genetics 5: 195-200.

3) Jishage $\mathrm{K}$, Arita M, Igarashi K, Iwata T, Watanabe M, Ogawa M, Ueda O, Kamada N, Inoue K, Arai H, Suzuki H. 2001. $\alpha$-Tocopherol transfer protein is important for the normal development of placental labyrinthine trophoblasts in mice. J Biol Chem 276: 1669-1672.

4) Leonard SW, Terasawa Y, Farese Jr RV, Traber MG. 2002. Incorporation of deuterated $R R R$ - or all-rac- $\alpha$-tocopherol in plasma and tissues of $\alpha$-tocopherol transfer protein-null mice. Am J Clin Nutr 75: 555-560.

5) Schock BC, Van der Vliet A, Corbacho AM, Leonard SW, Finkelstein E, Valacchi G, Obermueller-Jevic U, Cross CE, Traber MG. 2004. Enhanced inflammatory response in $\alpha$-tocopherol transfer protein null mice. Arch Biochem Biophys 423: 162-169.

6) Shaw H-M, Huang C-J. 1998. Liver $\alpha$-tocopherol transfer protein and its mRNA are differentially altered by dietary vitamin $\mathrm{E}$ deficiency and protein insufficiency in rats. J Nutr 128: 2348-2354.

7) Shaw H-M, Huang C-J. 2000. Secretion of $\alpha$-tocopherol in VLDL is decreased by dietary protein insufficiency in young growing rats. J Nutr 130: 3050-3054.

8) Yoshikawa T, Takemura S, Kondo M. 1982. Alpha-tocopherol level in liver diseases. Acta Vitaminol Enzymol 4: 311-318.

9) von Herbay A, Stahl W, Niederau C, von Laar J, Strohmeyer G, Sies H. 1996. Diminished plasma levels of vitamin $\mathrm{E}$ in patients with severe viral hepatitis. Free Radic Res 25: 461-466.

10) Ferre N, Camps J, Prats E, Girona J, Gomez F, Heras M, Simo JM, Ribalta J, Joven J. 2002. Impaired vitamin E status in patients with parenchymal liver cirrhosis: relationships with lipoprotein compositional alterations, nutritional factors, and oxidative susceptibility of plasma. Metabolism 51: 609-615.

11) Nagita A, Ando M. 1997. Assessment of hepatic vitamin E status in adult patients with liver disease. Hepatology 26: 392-397.

12) Keppler DOR, Pausch J, Decker K. 1974. Selective uridine triphosphate deficiency induced by D-galactosamine in liver and reversed by pyrimidine nucleotide precursors. J Biol Chem 249: 211-216.

13) Muntane J, Montero JL, Marchal T, Perez-Seoane C, Lozano JM, Fraga E, Pintado CO, De la Mata, Mino G. 1998. Effect of PGE1 on TNF-alpha status and hepatic D-galactosamine-induced apoptosis in rats. J Gastroenterol Hepatol. 13: 197-207.

14) Stachlewitz RF, Seabra V, Bradford B, Bradham CA, Rusyn I, Germolec D, Thurman RG. 1999. Glycine and uridine prevent D-galactosamine hepatotoxicity in the rat: role of kupffer cells. Hepatology 29: 737-745.

15) Tsutsui S, Hirasawa K, Takeda M, Itagaki S, Kuwamura S, Maeda K, Mikami T, Doi K. 1997. Galactosamineinduced apoptosis in the primary mouse hepatocyte cultures. Exp Toxicol Pathol 49: 301-306.

16) Sato Y, Arai H, Miyata A, Tokita $S$, Yamamoto K, Tanabe T, Inoue K. 1993. Primary structure of $\alpha$-tocopherol transfer protein from rat liver. J Biol Chem 268: $17705-$ 17710 .

17) Harada N, Saito S-I, Minakata K. 1991. Effects of vitamin $\mathrm{E}$ on toxicity of minute amounts of paraquat fed 
continuously to rats. J Nutr Sci Vitaminol 37: 1-13.

18) Sugimoto E, Igarashi K, Takenaka A. 2003. Preventive effect of dietary nasunin on galactosamine-induced liver injury in rats. Food Sci Technol Res 9: 94-99.

19) Wroblewski F, LaDue JS. 1955. Lactic dehydrogenase activity in blood. Proc Soc Exp Biol Med 90: 210-213.

20) Folch J, Lees M, Sloane-Stanley GH. 1957. A simple method for the isolation and purification of total lipids from animal tissues. J Biol Chem 226: 497-509.

21) Chomczynski P, Sacchi M. 1987. Single-step method of RNA isolation by acid guanidinium thiocyanate-phenol-chloroform exrtraction. Anal Biochem 162: 156159.

22) Puissant C, Houdebine L-M. 1990. An improvement of the single-step method of RNA isolation by acid guanidinium thiocyanate-phenol-chloroform extraction. BioTechniques 8: 148-149.

23) Miura Y, Kato H, Noguchi T. 1992. Effect of dietary proteins on insulin-like growth factor-1 (IGF-1) messenger ribonucleic acid content in rat liver. Br J Nutr 67: 257 265.

24) Kettermann R, Sirowej H. 1979. Liver injury and lipid metabolism: sex differences in the fatty liver induced by D-galactosamine. Acta Hepatogastroenterol 2: 112-121.

25) Mangeney-Andreani M, Sire O, Motagne-Clavel J, Nord- mann R, Nordmann J. 1982. Inhibitory effect of Dgalactosamine administration on fatty acid oxidation in rat hepatocytes. FEBS Lett 145: 267-270.

26) Gujral JS, Farhood A, Jaeschke H. 2003. Oncotic necrosis and caspase-dependent apoptosis during galactosamine-induced liver injury in rats. Toxicol Appl Pharmacol 190: 37-46.

27) Kucera O, Cervinkova Z, Lotkova H, Krivakova P, Rousar T, Muzakova V, Hezova R, Kandar R, Rudolf E. 2006. Protective effect of $S$-adenosylmethionine against galactosamine-induced liver injury of rat hepatocytes in primary culture. Physiol Res 55: 551-560.

28) Barrow L, Patel HR, Tanner MS. 1992. Alpha-tocopherol deficiency fails to aggravate toxic liver injury but liver injury causes alpha-tocopherol retention. J Hepatol 16: $332-337$.

29) Rocchi E, Borghi A, Paolillo F, Pradelli M, Casalgrandi G. 1991. Carotenoids and liposoluble vitamins in liver cirrhosis. J Lab Clin Med 118: 176-185.

30) Ravikumar V, Shivashangari KS, Devaki T. 2005. Effect of Tridax procumbens on liver antioxidant defence system during lipopolysaccharide-induced hepatitis in Dgalactosamine sensitized rats. Mol Cell Biochem 269: 131-136. 